Mehmet Akif Ersoy Üniversitesi Fen Bilimleri Enstitüsü Dergisi 11(2): 213-222 (2020)

The Journal of Graduate School of Natural and Applied Sciences of Mehmet Akif Ersoy University 11(2): $213-222$ (2020)

Araştırma Makalesi / Research Paper

\title{
Büyük Çamlıca Korusu’nun Peyzaj Tasarımı ve Kullanıcı Memnuniyeti Üzerine Bir Araştırma
}

\author{
Nurhan KOÇAN (D) ${ }^{*}$, Nur Banu METIN iD 1 \\ ${ }^{1}$ Bartın Üniversitesi, Mühendislik Mimarlık ve Tasarım Fakültesi, Peyzaj Mimarlığı Bölümü, Bartın \\ Geliş Tarihi (Received): 06.06.2020, Kabul Tarihi (Accepted): 03.09.2020 \\ $\square$ Sorumlu Yazar (Corresponding author*):nkocan@bartin.edu.tr \\ (C) +903782235158 且 +903782235042
}

ÖZ

Günümüz kentleşme sisteminde kentsel yeşil alanların, kentlilerin yaşam kalitesini artırmadaki rolü oldukça önemlidir. Kentli insanların kent ortamında maruz kaldıkları stresli yaşam temposu ruhsal ve bedensel sağlıklarını olumsuz yönde etkilemektedir. İnsanlar kentlerde nefes alabilecekleri kentsel açık yeşil alanlara ihtiyaç duymaktadır. Kent parkları insanların yeşil alan ihtiyacını karşılayan aynı zamanda kentlerin kendilerine özgü yapısal ve bitkisel öğelerini barındıran en önemli alanlardır. Araştırma alanı İstanbul İli Üsküdar İlçesinde yer alan Büyük Çamlıca Korusu'dur. Çalışmanın amacı Büyük Çamlıca Korusu'nun ulaşılabilirlik, alan kullanımları, yapısal ve bitkisel elemanları yönünden kullanıcı memnuniyetini değerlendirmek, farklı fiziksel, sosyal ve kültürel yapıdaki insanların kentsel açık yeşil alan intiyaçlarını aynı anda karşılayabilmeleri için geliştirilen önerilerle alanın rekreasyonel kalitesini artırmaktır. Çalışma kapsamında alanın bitkisel tasarımları, yapısal donatı ve alan kullanımları irdelenmiştir. Alanda 384 kişiyle 16 sorudan oluşan anket yapılmıştır. Anket cevapları analiz edilerek alanın peyzaj tasarımı ve kullanım planlaması ile ilgili kullanıcı memnuniyeti ortaya konulmuştur.

Anahtar Kelimeler: Büyük Çamlıca, kent parkı, koru, peyzaj tasarımı, Üsküdar

\section{A Research on Landscape Design and User Satisfaction of Büyük Çamlıca Grove}

\begin{abstract}
In today's urbanization system, the role of urban green lands in improving the life quality of the urban residents is very important. The urban residents are exposed to stressful life in the urban environment because urban life negatively effects their mental and physical health. People need urban open green lands where they can breathe in the cities. Urban parks are the most important areas that meet the green land needs of the people and at the same time contain the structural and vegetative elements of the cities. The case area is Büyük Çamlıca Grove in Üsküdar District of Istanbul Province. The aim of the study is to evaluate the user satisfaction of Büyük Çamlıca Grove in terms of accessibility, land uses, structural and vegetative elements and to increase the recreational quality of the area with the suggestions developed so that people of different physical, social and cultural structures can meet the urban open green land needs at the same time. Within the scope of the study, vegetative designs of the area, structural reinforcement and area uses were examined. A questionnaire consisting of 16 questions was conducted with 384 people in the area. Questionnaire responses were analyzed and user satisfaction regarding landscape design and usage planning of the area was revealed.
\end{abstract}

Keywords: Büyük Çamlıca, urban park, grove, landscape design, Üsküdar 


\section{Giriş}

Kentlerde yaşam dinamiklerinin hızı ve ritmi yaşam kalitesini etkilemekte ve birçok yönden kentliler için yorucu bir hal almaktadır. Kentler kültürel çeşitliliğin ve sosyal yaşamın merkezi olmasına rağmen, insanlar yoğunlaşmış iş alanlarının içinde doğaya ve yeşil alanlara özlem duymaktadır. Kent parkları insanların bu türden intiyaçlarını karşılayan sosyal iletişimin en güçlü olduğu alanlardır (Akpınar, 2013).

Önceden insanların dinlenme, eğlenme, sosyalleşme rekreasyon vb. kent parkı işlevlerini sağlayan alanlar koru adı verilen kent içi yeşil alanlardan oluşturulmuştur. Günümüzde kent parkı olarak kullanılan koruların peyzaj tasarım çalışmalarıyla özgünlüklerinin geliştirilerek korunması ve kentsel açık yeşil alan sistemi içerisinde kullanılması amaçlanmaktadır. Önerilen peyzaj tasarımlarının kullanım alanlarının işlevlerini engellememesi ve her yaş grubundan insanların kullanımına açık olması hedeflenmektedir. Kent parkı olarak kullanılan korularda yapılan peyzaj düzenlemeleri korularda yer alan tarihi ağaçları, tarihi yapıları ve tarihi dokuyu bozmamalıdır. Koruların mikro klima etkileri gözetilerek gelecek nesillere en iyi şekilde ulaşması için doğru şekilde kullanılması kentin tarihi güzelliklerine katkı sağlaması açısından önemlidir (Albayrak, 2000).

Günümüze kadar gelebilmiş korular kent parkı olarak hizmet vermekte kentin açık yeşil alan sistemine katılarak birçok fonksiyonu yerine getirmektedirler (Albayrak, 2000);

- Yerleşim alanlarının kent içindeki fiziksel dengesini sağlarlar.

- Kentlerin mimari formuna katkı sağlayarak aralarında uyumsuzluk gösteren ticaret ve endüstri gibi farklı alanlar arasında tampon görevi yaparlar.

- Kentin içerisinde ışık ve hava kaynağı sağlarlar ve alanlar arasında gürültü perdesi oluştururlar.

- Doğal filtre işlevi görerek kentlere mikroklimatik işlev sağlarlar.
- Rekreasyonel amaçlar için planlanmış bu alanlar kentlilere aktif ve pasif rekreasyon imkanı sağlarlar.

- Kentlerin yapısını değiştirerek monotonluğu giderirler. Mekanlar arasında bağlayıcı özellik gösterirler. Böylelikle bir yandan kentin fiziksel yapısını yenileyerek diğer yandan da kentin sert mimari yapısını yumuşatırlar.

- Kent içinde insanla doğa arasında iletişim imkanı sağlarlar.

- Insanların yaşadığı mekanları keşfetmesini sağlarlar.

- Yapıların insan üstündeki baskısını hafifletirler.

- Kentlere estetik yönden hizmet ederler.

\section{MATERYAL VE YÖNTEM}

\section{Materyal}

Çalışma alanı İstanbul İli Üsküdar İlçesindeki Büyük Çamlıca Korusu'dur. Çalışmanın amacı kent parkı kullanımında olan Büyük Çamlıca Korusu'nda yapılan peyzaj düzenlemelerini ekolojik açıdan, ulaşım açısından, sosyo-kültürel açıdan, rekreasyon açısından değerlendirmektir. Alanın var olan kullanım alanlarını kent parklarında bulunması gereken kullanım alanlarıyla kent parkı planlama ilkeleri kapsamında karşılaştırarak alanın tarihi dokusunu bozmadan geliştirmek hedeflenmektedir. Çalışmada yardımcı materyal olarak konuyla ilgili daha önce yapılmış çalışmalar, harita ve ilgili kurumlarla yapılan görüşmeler sonucu elde edilen veriler kullanıımıştır.

Üsküdar, İstanbul'un Anadolu yakasının en eski ilçesidir. Kuzeyden Beykoz, kuzeydoğudan Ümraniye, doğudan Ataşehir, güneyden Kadıköy ilçeleri ve batıdan İstanbul Boğazı'yla çevrilidir (Şekil 1). İstanbul Boğazı'na olan sahil uzunluğu 12 kilometredir. İlçenin en yüksek noktası olan Büyük Çamlıca Tepesi 268 metre yüksekliğindedir (URL-1, 2019).

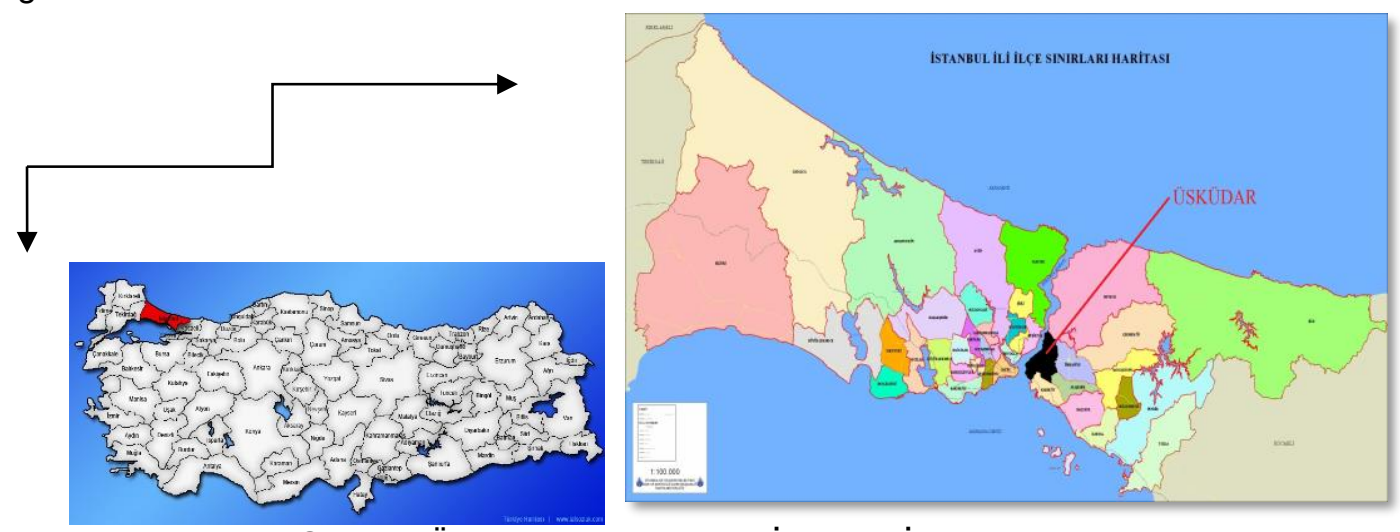

Şekil 1. Üsküdar'ın Türkiye ve İstanbul İli içindeki konumu 
Üsküdar iklim yönünden Marmara Bölgesi'nin karakteristik özelliğini gösterir. Marmara'nın ılıman havası ile Balkanlar'dan gelen soğuk hava etkisi altında bulunur. Yazları sıcak ve kurak, ilkbahar, sonbahar ve kış ayları ise genelde yağmurlu geçer. Yıllık ortalama sıcaklık 15 derecedir. Yıllık ortalama yağış miktarı metrekare başına 650-700 kg'dır. Ortalama nispi nem \%75'tir (URL1, 2019).

Üsküdar İstanbul'un Avrupa yakasından Anadolu yakasına geçişteki merkez noktada yer almaktadır. Eminönü, Beşiktaş ve Kabataş vapur seferleri ile Harem Sirkeci feribot seferlerinin gerçekleştiği Üsküdar, bu yönüyle deniz ulaşımında kilit rol oynamaktadır. Boğaz Köprüsü ve bağlantı yollarının merkezinde bulunması sebebiyle karayolu ulaşımında da aktif olan Üsküdar, Marmaray'ın 2013 yılında hizmete girmesiyle ulaşımdaki stratejik önemini arttırmıştır (URL-1, 2019).

\section{Yöntem}

Çalışmada öncelikle konu ile ilgili literatür taraması yapılmıştır. Alan farklı mevsim, gün ve saatlerde ziyaret edilerek yerinde gözlemlenmiş ve fotoğraflar çekilmiştir. Alanda yapılan peyzaj düzenlemeleri kent parkı kullanımları ve tasarımları açısından irdelenmiştir. Kullanıcıların alanda yapılan peyzaj düzenlemelerini ne şekilde kullandığı, alandan beklentileri ve kullanıcı memnuniyeti kapsamında bir anket çalışması yürütülmüştür. Üsküdar'ın nüfus verilerine göre anket yapılacak kişi sayısı belirlenmiştir. Türkiye İstatistik Kurumu (TUIK) Adrese Dayalı Nüfus Kayıt Sistemi Veri Tabanından alınan 2018 yılı nüfus verilerine göre Üsküdar'ın nüfusu 529.145 kişidir (URL-2, 2019). Anketlerin uygulanması kısmında örneklem büyüklüğü Newbold (1995)'e göre
Oransal Örnek Hacmi Formülünü veren aşağıdaki formül (Denklem 1) kullanılarak belirlenmiştir. \%95 güven aralığında ve $\% 5$ hata payı göz önüne alınarak, yerel halka en az 384 anket uygulanması gerektiği tespit edilmiştir (URL-3, 2019). Ankette kişilere konu ile ilgili 16 soru yöneltilmiştir.

- $\mathrm{n}$ : Örneklem büyüklüğü

- N: Ana kütle büyüklüğü (Çalışma alanının toplam nüfusu 529.145)

- $Q_{P_{X}}^{3}$ : Oranın Varyansı (0.0255102)

- $p:$ Oran (p:0.5)

$$
\mathrm{n}=\frac{\mathrm{Np}(1-\mathrm{p})}{(\mathrm{N}-1) Q_{P_{X}}^{3}+\mathrm{p}(1-\mathrm{p})}
$$

$n=384$.

\section{BULGULAR}

\section{Çalışma Alanının Kent Parkı Kullanımları ve Peyzaj Düzenlemeleri Açısından İrdelenmesi}

Büyük Çamlıca Korusu Üsküdar ilçesinde olup $154.147,98 \mathrm{~m}^{2}$ alana sahiptir (Şekil 2). Alanda 4 adet çocuk oyun alanı, 1 adet aletli spor alanı, sosyal tesis ve süs havuzu bulunmaktadır. Adını Üsküdar ile Ümraniye arasındaki iki yüksek tepeden biri olan Büyük Çamlıca tepesinden alan koruluk, bir takım çatlaklarla parçalanmış olan kuvarsitlerden süzülen içimi çok güzel su kaynaklarına sahiptir. İstanbul'un 360 derece panoramik olarak izlenebileceği bu tepe yüksekliği nedeniyle frekans yayıcıları, baz istasyonları için de kullanılmaktadır (URL-4, 2019).

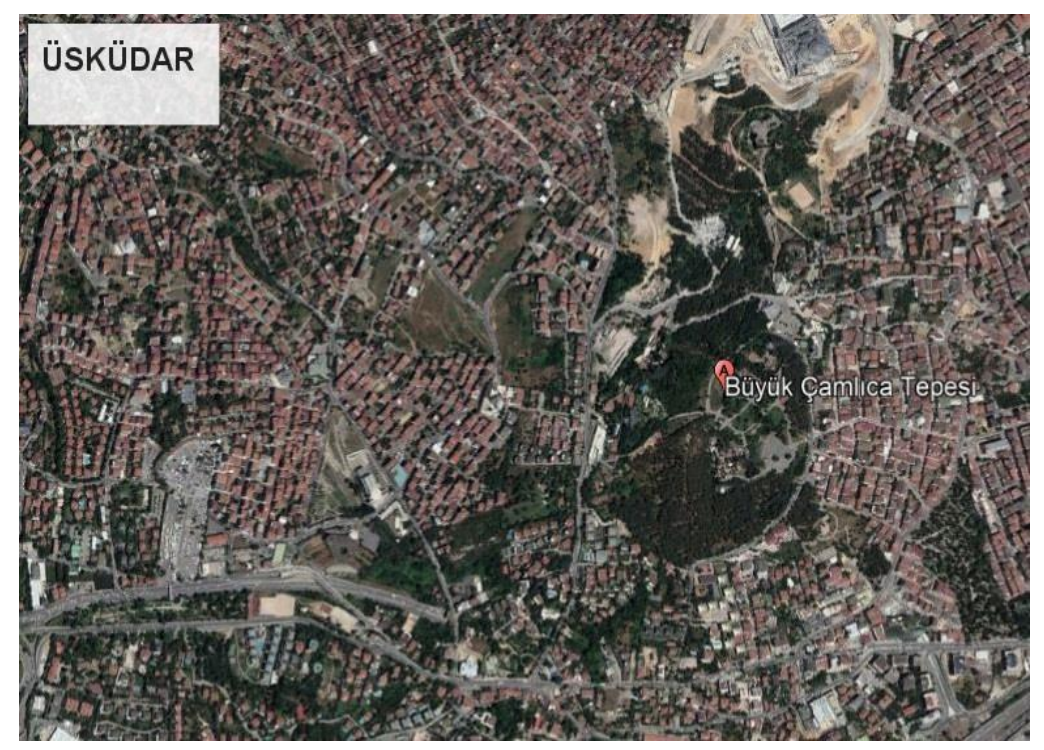

Şekil 2. Büyük Çamlıca Korusu uydu görüntüsü 
Kent yaşamının yoğun olduğu bir konumda bulunan çaıışma alanı insanların yeşil alan intiyacını ve kent parkı işlevleriyle bir çok aktivite imkanını kentlilere sağlamaktadır. Alanın koru olması sebebiyle içinde birçok tarihi ağaç bulunmaktadır. İstanbul peyzajına hakim manzarası, alan içerisindeki doğal yapının bozulmamış olması, yüksek konumu ve sık ağaçları ile küçük bir orman havası vermesi kullanıcıların alanı seçmesinde etken ol- maktadır. Alandaki tarihi dokuların günümüze kadar gelebilmesi ve sonradan beton yapılanmanın olmaması alanı farklı kılan diğer özelliktir. Alanın boğazın iki köprüsüne hakim manzarası alanda özel gün fotoğraf çekimi gibi aktivitelere imkan sağlamaktadır. Alan içerisinde yeşil alanlarda yapılan bitkisel düzenlemelerde bahar mevsimi geldiğinde baskın olarak lale kullanıldığı gözlenmiştir. Alanda fıstık çamı, kızılçam gibi ağaç türleri bulunmaktadır (Şekil 3a, 3b).
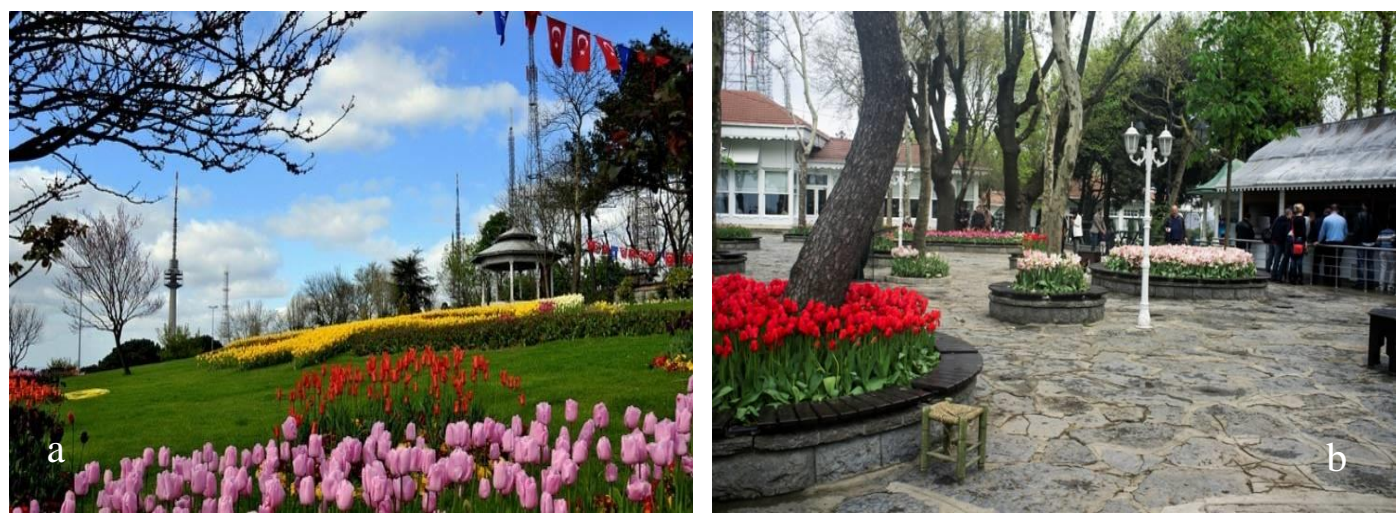

Şekil 3 a, b. Büyük Çamlıca Korusu'ndan görünümler (URL-4, 2019).

Alanda bulunan sosyal tesis ziyaretçilere açık ve kapalı yeme-içme mekanı sunmaktadır. Açık alanda oturma ve aydınlatma birimi bulunmaktadır. Oturma birimleri ferforje ve hasır banklardan yapılmıştır (Şekil 4a). Yaz aylarında manzaraya hakim yürüme yollarında Osmanlı macunu satıcıları gibi birçok seyyar satıcı görülmektedir. Alanın yerel halka ticari gelir sağladığı tespit edilmiştir. Sosyal tesisin açık alanının zemininde kayrak taşı kullanılmıştır. Sosyal tesiste mermer materyalden büfe gibi satış birimlerinin olduğu gözlenmiştir. Alanda kullanılan malzemeler alanın doğal yapısına uygun ve uzun ömürlü materyallerden tercih edilmiştir (Şekil 4b).

Alanda akşam saatlerinde yapılan ışıklandırmalar kapalı mekanların dokusuna renk katmaktadır. Alanın yaz kış ziyaret edildiği gözlenmiştir. Sosyal tesislerin kapalı mekanlarında canlı müzik gibi birçok aktivite yapılmaktadır. Alanda çocuk oyun parkı ve mesire alanı bulunmaktadır.
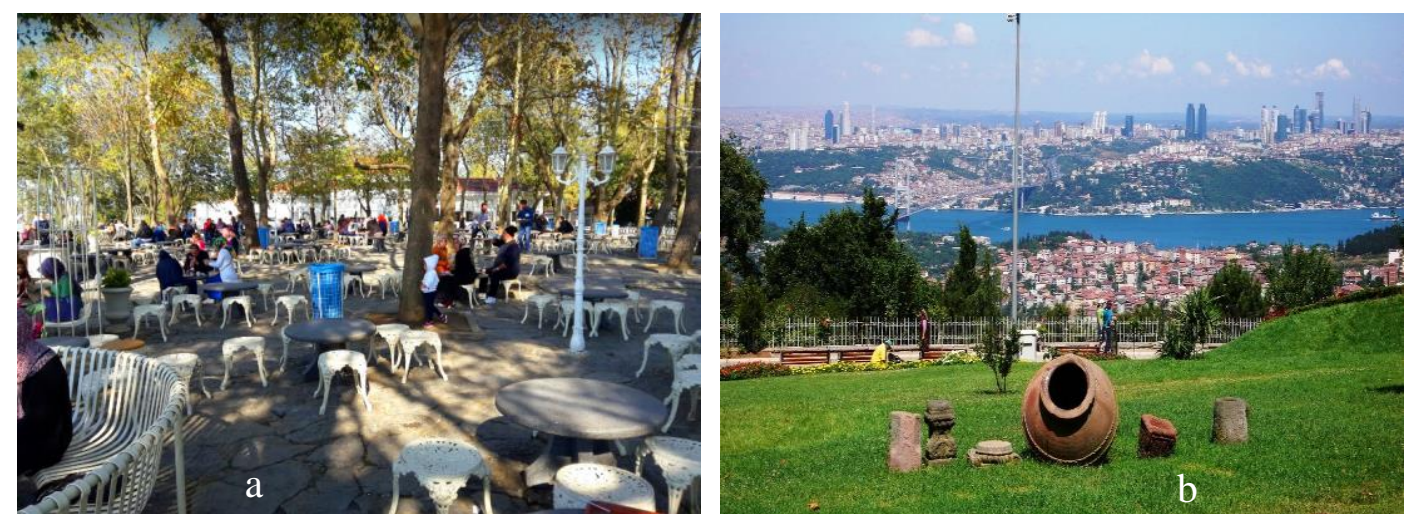

Şekil 4 a. Büyük Çamlıca Korusu sosyal tesisi açık alanından bir görünüm, b. Büyük Çamlıca Korusu yeşil alandaki objelerden bir görünüm

Yapılan bitkilendirme çalışmaları yol aksı ile yeşil zemini birbirinden ayırmakta yol kenarlarında renk harmonisi oluşturarak ziyaretçilere eşlik etmektedir. Birçok etkinlik için ziyaret edilen alanda yaya yollarında rahatça dolaşımın olması alandaki yol genişlik ölçülerinin teknik olarak 
doğru hesaplandığını göstermektedir. Düzenli bir otoparka sahip olan alanda yalnızca Çamlıca Tepesi yokuşuna kadar otobüs ve minibüslerle ulaşımın olması otoparkın yeterli genişlikte olmadığını göstermektedir (Şekil $5)$.

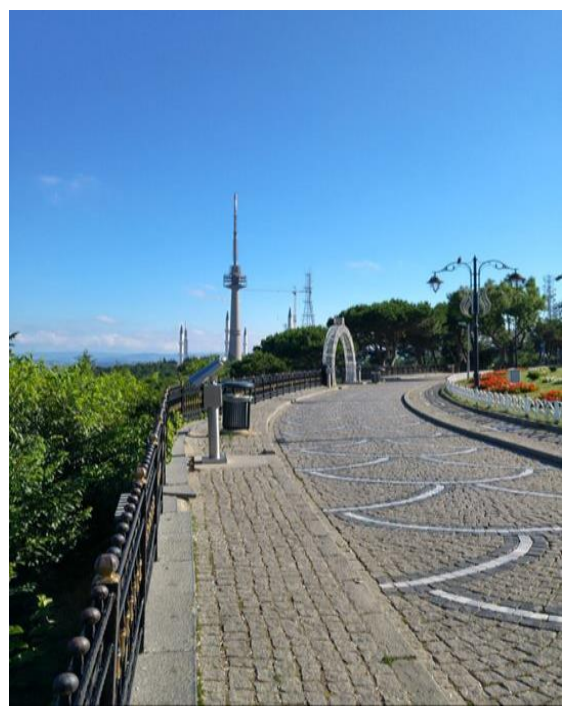

Şekil 5. Büyük Çamlıca Korusu yaya yolundan bir görünüm

Büyük Çamlıca Korusu 1/1000 ölçekli halihazır haritasında işaretlenmiş alanlarda aşağıda belirtilen değerlendirmeler yapılmıştır (Şekil 6);

- 1. bölge sosyal tesislerin bulunduğu alandır. Sosyal tesis alanın doğal peyzajına uygun olarak manzaraya hakim olarak konumlandırılmıştır. Alandaki ışıklandırma alanı vurgulamakta ve gece görüşünü artırmaktadır.

- 1. bölgede kullanılan kent donatılarının dokusu alanla uyumludur.

- 2. bölge köprü ve adalar manzarasına hakim olup seyir terası işlevi gören bir gezinti yoludur.

- 1. ve 2. bölge arasında yapılan bitkisel düzenlemeler renk, şekil ve formları ile yeşil alanları vurgulamaktadır.

- 3. bölge otoparkların bulunduğu alandır. Bu alan sosyal tesisin girişinde bulunmaktadır. 1. ve 2. bölgeye geçiş olanağı sağlamaktadır. Otoparkın geniş ve düzenli olması rahat bir şekilde park edilip çıkılmasını sağlamaktadır.

- 3. bölge ve 2. bölge arasındaki geçiş merdivenlerle sağlanmaktadır. Merdivenlerde bulunan ferforje korkuluklar merdiven alanının görünümünü güzelleştirir.

- 4. bölgede verici istasyonları vardır. 2. bölge ve 4 . bölge arasında park alanı vardır. Bu alan aynı zamanda piknik alanı olarak bırakılan doğalığı bozulmamış bir alandır.

- 4. bölgede alanın bir girişi daha vardır. Bu alanda da otopark mevcuttur.

- Yol sirkülasyonu 3. bölgedeki otoparktan başlayarak alanların arasında dolaşıp 4.bölgedeki otopark alanına kadar devam eder. Bu da alandaki hareket ve dinamikliği gösterir. 


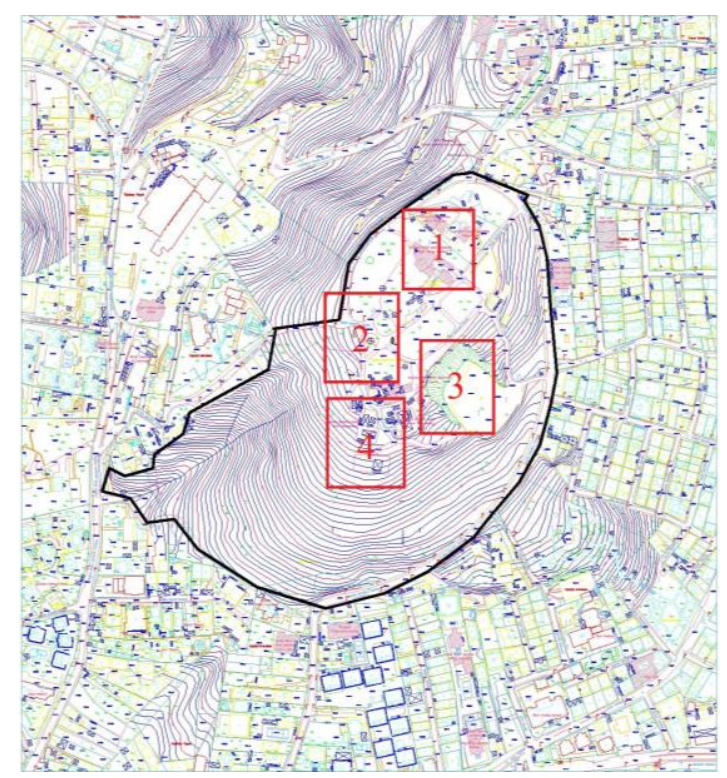

Şekil 6. Büyük Çamlıca Korusu 1/1000 ölçekli halihazır haritası

\section{Anket Çalışmaları}

Alanda anket çalışması yürütülmüştür. Anketlerin uygulanması kısmında örneklem büyüklüğü Newbold (1995)'e göre Oransal Örnek Hacmi Formülü kullanılarak, $\% 95$ güven aralığında ve $\% 5$ hata payı göz önüne alınarak, yerel halka en az 384 anketin uygulanması gerektiği sonuçlar doğrultusunda tespit edilmiştir. Tespit edilen sayıda kişi ile yapılan anket çalışmasına ilişkin aşağıdaki sonuçlara ulaşılmıştır.

Uygulanan anket sayısı içerisinde alanları ziyaret eden kullanıcıların \%41.16'sı 18-25, \%25.52'si 26-35, $\% 24.73$ 'ü 56-65, \%1.56'sı 66 ve üstü yaş aralığındadır. Yürütülen ankette uygulanan 384 kişi arasında alanları en çok ziyaret eden bireylerin 18-25 yaş aralığında, en az ziyaret eden bireylerin 66 ve üstü kimseler olduğu görülmektedir.

Yürütülen ankette ziyaretçilerinin eğitim durumuna bakıldığında ilköğretim mezunu kişiler \%28.92, lise mezunları $\% 32.55$, üniversite mezunları $\% 36.45$ ve lisansüstü mezunları \%2.84'tür. Alanı kaç kere ziyaret ettiniz sorusuna verilen yanıtlar Tablo 1'de, alana haftada kaç kez gidersiniz sorusuna verilen yanıtlar Tablo 2'de görülmektedir.

Alanı ziyaret amacınız sorusuna verilen yanıtlar Tablo 3'te görülmektedir.

Alandaki spor tesisi, dinlenme alanları, yapısal ve bitkisel donatının yeterliliğine ilişkin sorulara verilen yanıtlar Tablo 4'te gösterilmiştir.

Tablo 1. Alanın kullanım analizi

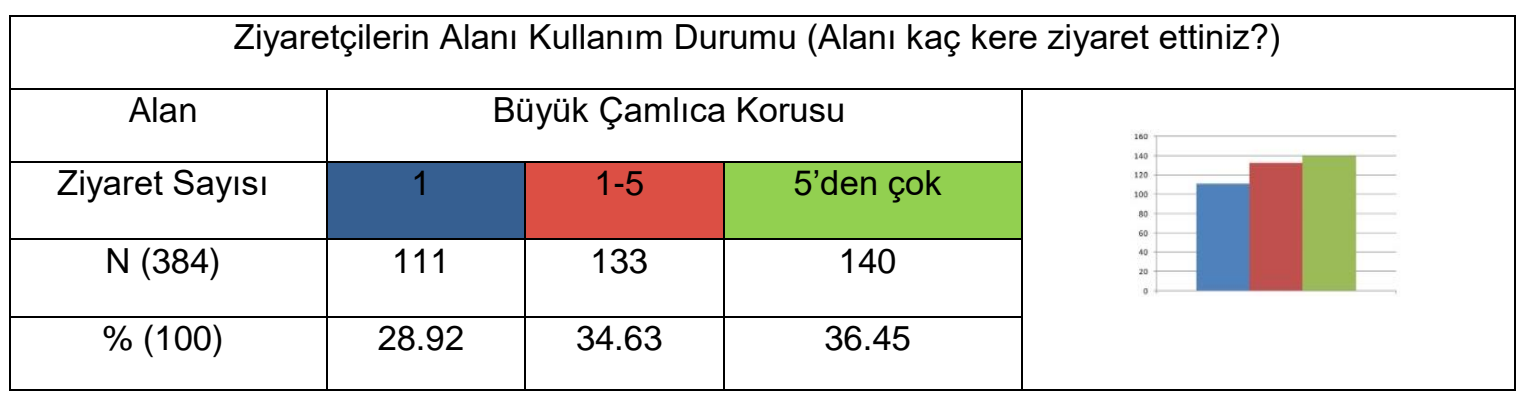


Tablo 2. Alana gidiş sıklığı analizi

\begin{tabular}{|c|c|c|c|c|c|}
\hline \multicolumn{5}{|c|}{ Ziyaretçilerin Alanlara Gidiş Durumu (Alana haftada kaç kez gidersiniz?) } \\
\hline Alan & \multicolumn{5}{|c|}{ Büyük Çamlıca Korusu } \\
\hline $\begin{array}{c}\text { Ziyaret Sık- } \\
\text { lığı }\end{array}$ & $\begin{array}{c}\text { Haftada } \\
1\end{array}$ & $\begin{array}{c}\text { Haftada 1'den } \\
\text { fazla }\end{array}$ & Ayda 1 & Yılda 1 & Hiç \\
\hline $\mathrm{N}(384)$ & 70 & 63 & 80 & 166 & 5 \\
\hline$\%(100)$ & 18.22 & 16.40 & 20.83 & 43.25 & 1.30 \\
\hline
\end{tabular}

Tablo 3. Alanların ziyaret amacı analizi

\begin{tabular}{|c|c|c|c|c|c|c|}
\hline \multicolumn{7}{|c|}{ Ziyaretçilerin Alanlara Gidiş Amacı (Alanı ziyaret amacınız?) } \\
\hline Alan & \multicolumn{6}{|c|}{ Büyük Çamlıca Korusu } \\
\hline $\begin{array}{l}\text { Ziyaret } \\
\text { Nedeni }\end{array}$ & $\begin{array}{l}\text { Yeme } \\
\text { İçme }\end{array}$ & Dinlenme & $\begin{array}{c}\text { Fotoğraf } \\
\text { Çekme }\end{array}$ & Eğlenme & Yürüyüş & Diğer \\
\hline $\mathrm{N}(384)$ & 76 & 70 & 76 & 66 & 60 & 36 \\
\hline$\%(100)$ & 19.82 & 18.22 & 19.79 & 17.18 & 15.62 & 9.37 \\
\hline
\end{tabular}

Tablo 4. Büyük Çamlıca korusu durum analizi

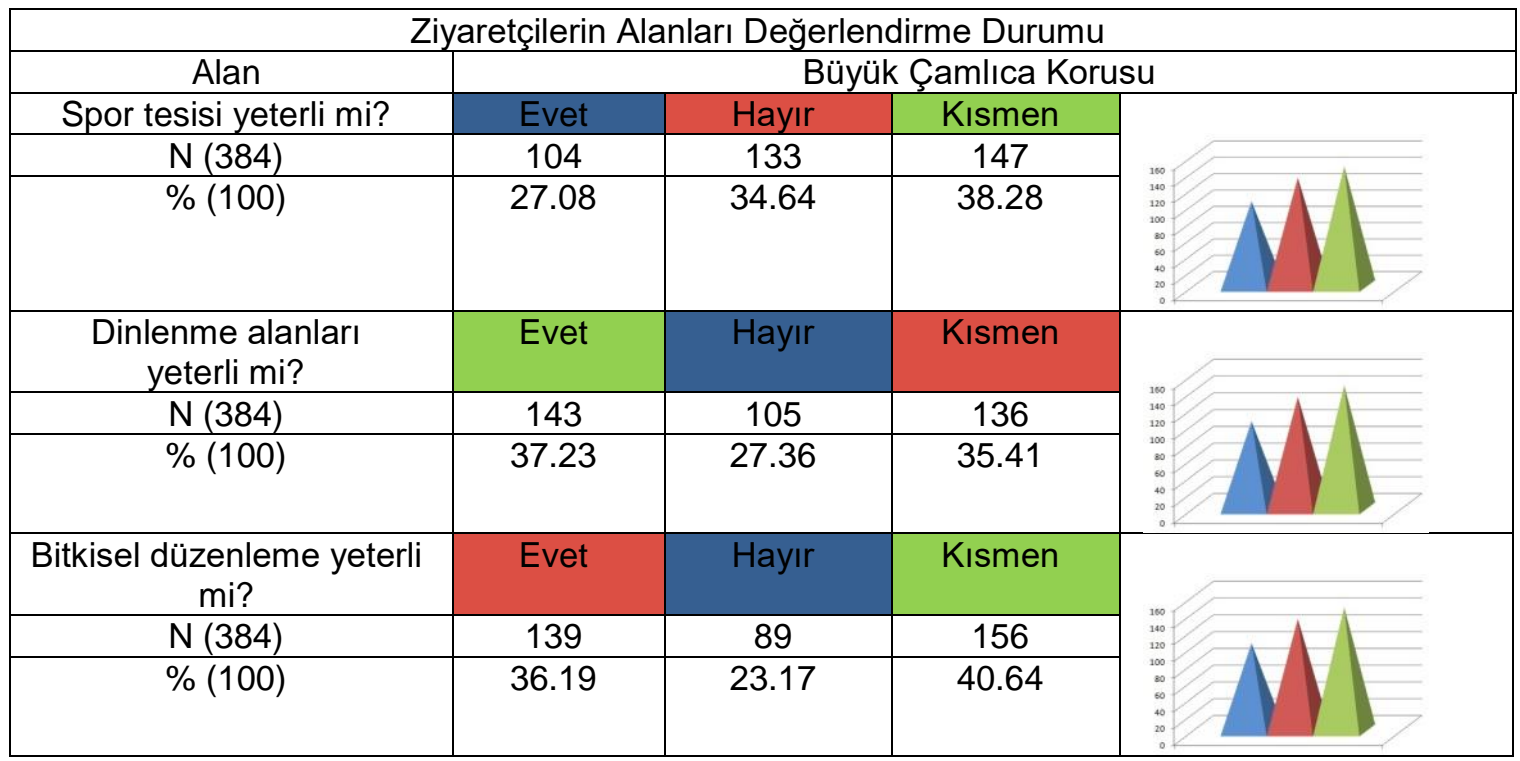

Alandaki aydınlatma ögesi, oturma birimi, çöp kovası, pano, yönlendirme tabelası, oyun elemanı yeterliliğine ilişkin sorulara verilen yanıtlar Tablo 5'te, açık dinlenme alanı, kapalı dinlenme alanı ve ulaşım durumunun yeterliliğine ilişkin sorulara verilen yanıtlar Tablo 6'da göste- rilmiştir. Anket sonuçlarında kent donatısı \%59.38 yetersiz, \%40.62 ise yeterli çıkmıştır. Alandaki en büyük eksikliğin ulaşım ile açık ve kapalı dinlenme alanı yetersizliği olduğu görülmüştür. 
Tablo 5. Büyük Çamlıca Korusu kent donatısı durum analizi

\begin{tabular}{|c|c|c|c|c|}
\hline \multicolumn{5}{|c|}{ Ziyaretçilerin Alandaki Kent Donatılarını Değerlendirme Durumu } \\
\hline Alan & & Büyük & usu & \\
\hline Durumu & \multicolumn{2}{|c|}{ Yeterli } & \multicolumn{2}{|c|}{ Yetersiz } \\
\hline N-\% Durumu & $\mathrm{N}$ & $\%$ & $\mathrm{~N}$ & $\%$ \\
\hline Aydınlatma Ögesi & 280 & 72.91 & 104 & 27.09 \\
\hline Oturma Birimi & 287 & 74.73 & 97 & 25.27 \\
\hline Cöp Kovası & 275 & 71.61 & 109 & 28.39 \\
\hline Pano & 270 & 70.31 & 114 & 29.68 \\
\hline $\begin{array}{c}\text { Yönlendirme Tabe- } \\
\text { lası }\end{array}$ & 247 & 64.32 & 137 & 35.68 \\
\hline Oyun Elemanı & 156 & 40.62 & 228 & 59.38 \\
\hline
\end{tabular}

Tablo 6. Büyük Çamlıca korusu eksiklik analizi

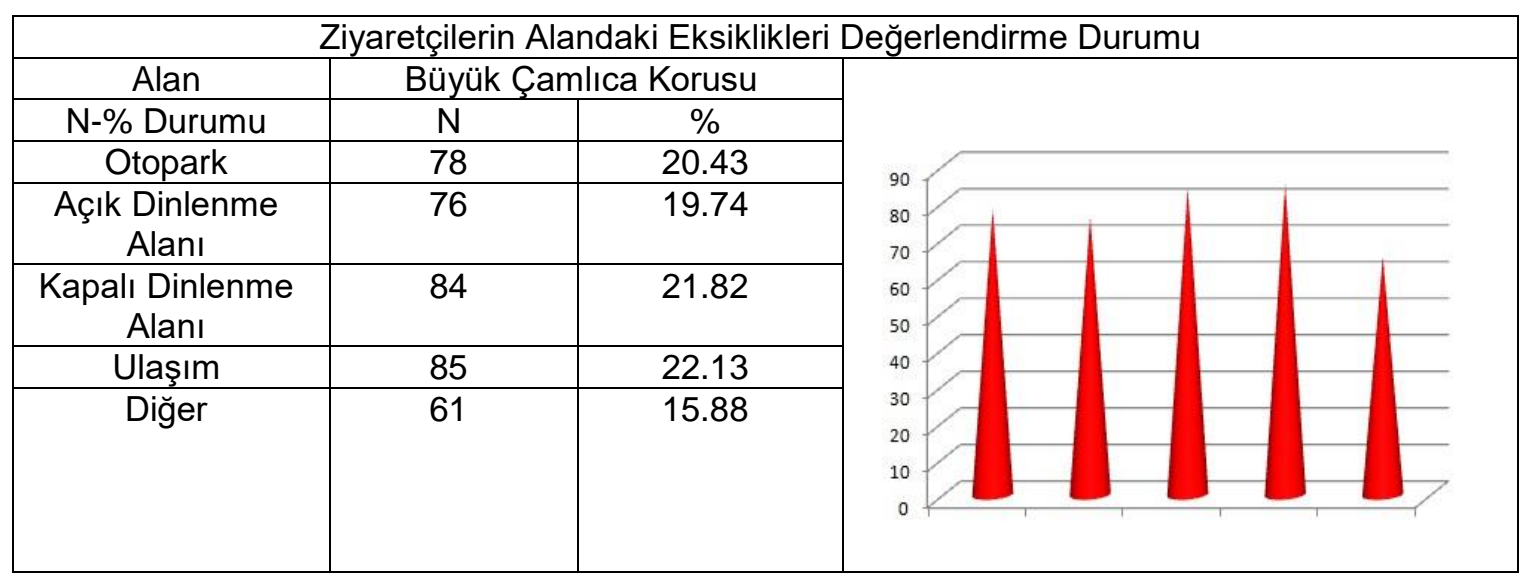

\section{SONUÇ VE ÖNERILER}

Büyük Çamlıca Korusu değerlendirildiğinde aşağıdaki sonuçlara ulaşılmıştır (Tablo 7, Tablo 8).

Tablo 7. Büyük Çamlıca Korusu'nun kent parkı işlevlerine göre değerlendirilmesi

\begin{tabular}{|c|l|l|l|l|l|l|l|l|}
\hline \multicolumn{7}{|c|}{ Kent Parkı İşlevlerine Göre Değerlendirme } \\
\hline & $\begin{array}{l}\text { Arazi } \\
\text { İşlevi }\end{array}$ & $\begin{array}{l}\text { Ekolojik } \\
\text { İşlevi }\end{array}$ & $\begin{array}{l}\text { Sağlık } \\
\text { İşlevi }\end{array}$ & $\begin{array}{l}\text { Sosyal İşlevi } \\
\text { İsonomik }\end{array}$ & $\begin{array}{l}\text { Rekreas. } \\
\text { İşlevi }\end{array}$ & $\begin{array}{l}\text { Eğitim } \\
\text { İşlevi }\end{array}$ & $\begin{array}{l}\text { Kültürel } \\
\text { İşlevi }\end{array}$ \\
\hline Var & & & & & & & & \\
\hline Yok & & & & & & & & \\
\hline Kısmen & & & & & & & & \\
\hline
\end{tabular}


Tablo 8. Büyük Çamlıca Korusu'nun kalite kriterlerine göre değerlendirilmesi

\begin{tabular}{|c|c|c|c|c|}
\hline & & KRİTERLERINN & RE DEĞERLEN & \\
\hline & Erişilebilirlik & Konfor & Ulaşılabilirlik & Sosyallik \\
\hline & Yaş Grubu & $\begin{array}{c}\text { Kullanım Du- } \\
\text { rumu }\end{array}$ & $\begin{array}{l}\text { Alan } \\
\text { Bilgisi }\end{array}$ & Ziyaret Amacı \\
\hline & Cinsiyet & Donatı Durumu & $\begin{array}{l}\text { Ulaşım } \\
\text { Durumu }\end{array}$ & \\
\hline & $\begin{array}{l}\text { Eğitim } \\
\text { Durumu }\end{array}$ & Eksiklikler & $\begin{array}{l}\text { İkamet } \\
\text { Durumu }\end{array}$ & \\
\hline & $\begin{array}{l}\text { Ziyaret } \\
\text { Sıklığı }\end{array}$ & & $\begin{array}{l}\text { Ziyaret } \\
\text { Durumu }\end{array}$ & \\
\hline & $\begin{array}{l}\text { Kullanım } \\
\text { Durumu }\end{array}$ & & & \\
\hline Var & & & & \\
\hline Yok & & & & \\
\hline Kısmen & & & & \\
\hline
\end{tabular}

- Alan içinde aydınlatma öğesi, çöp kovası, yönlendirme levhasının yeterli olması alanın rekreasyon işlevini olumlu etkilemektedir.

- Alanda açık ve kapalı oturma birimlerinin yeterli olması alanın daha çok tercih edilmesine sebep olmaktadır. Bu da alanın sosyal ve kültürel işlevine olumlu katkı sağlamaktadır.

- Çocuk oyun alanı elemanlarının yetersiz olması kullanıcıların tercihini olumsuz etkilemektedir.

- Alanda toplu ulaşım sistemi yeterli değildir. Bu durum alana ziyaretlerin özel araç ile yapılmasına sebep olurken otopark intiyacını artırmakta, çevreye araçlardan yayılan gaz ve tozların artışına neden olmaktadır.

- Spor tesislerinin kısmen yeterli olması ve yürüyüş amacı ile çok tercih edilmemesi alanın sağlık işlevini olumsuz etkilemektedir.

- Alandaki bitkisel düzenlemelerin bazı yerlerde yetersiz olduğu görülmektedir. Bu da alanın ekolojik işlevini olumsuz yönde etkilemektedir.

- Alandaki dinlenme alanlarının yeterli olması alanı ziyaretçilerin daha çok tercih etmesine fırsat vermekte böylece alanın sosyal ve kültürel işlevini olumlu yönde etkilemektedir.

- Alanın en çok yeme içme mekanı olarak tercih edilmesi alanın ekonomik işlevini olumlu etkilemektedir.

- Alanda farklı amaçlara yönelik aktivite ortamının olması alanı farklı yaş ve özellikte kullanıcıların tercih edebilmesine dolayısıyla alanın sosyal ve kültürel işlevine olumlu katkı sağlamaktadır.

- Alan içerisine taşıtların girmemesi alanın rekreasyon işlevine olumlu katkı sağlamakta, güvenli bir ortam oluşturmaktadır.

- Alanın doğal yapısı sebebiyle düz olması görüş açısından herhangi bir engele neden olmamakta böylece alanın bütün manzaraya hakim olmasını sağlamaktadır. Bu alanın ekonomik işlevine olumlu katkı sunmaktadır.

- Alanı her yaş grubundan, her cinsiyetten ve farklı eğitim durumuna sahip ziyaretçilerin ziyaret edebilmesi, alanın her mevsim ziyaret edilerek yılda 5 'den çok ziyaret edilmesi alanın erişilebilir olduğunu göstermektedir.

- Alanda donatılar, sosyal tesis alanları, bitkilendirmelerin yeterli olması alanın konforlu olduğunu göstermektedir.

- Alanın biliniyor olması, ziyaretçilerin çoğunluğunun İstanbul'da yaşayanlar olması ve alanın yaz-kış yoğun olarak ziyaret edilmesi alanın ulaşılabilirliğinin olduğunu göstermektedir.

Büyük Çamlıca Korusu'nda görülen eksikliler için çözülmesi gereken noktalar bulunmaktadır. Alanın toplu taşıma ile ulaşım sorununun çözülmesi gerekmektedir. Bitkisel düzenlemelerin artırılması spor tesislerinin çoğaltılması gerekmektedir.

Dünya'da geniş yeşil alan miktarına sahip kent parkları; içinde kent donatıları, sosyal tesisleri, spor alanları gibi birçok aktivitenin yapılabildiği alanlara sahiptir. Bitkilendirme çalışmalarının yanı sıra bilimsel faaliyetlerin gerçekleştirildiği alanları barındırması alanların eğitici yönlerini de ortaya koymaktadır. Bu alanda da çocuklar ve yetişkinler için düzenlenmiş bilimsel etkinlik alanları tasarlanması alana farklı bir kimlik katacaktır.

Birçok konser, festival ve etkinliklere ev sahipliğini yapan alanlar yeteri kadar geniş ve her kesimden ziyaretçilerin intiyacını karşılayan alanlardır. Bu alanlar erişilebilirlik, konfor, ulaşılabilirlik ve sosyallik açısından üst düzeydedir. Büyük Çamlıca Korusu da bu tür etkinlikler için uygundur. Toplu ziyaret kapasitesi öngörülerek bu türden sanatsal etkinlikler düzenlenirse alanın tanıtımı artacaktır. 


\section{KAYNAKLAR}

Akpınar, A. (2013). Kentsel Açık Alanlar: Başarılı Bir Kentsel Açık Alan İçin Gerekli Olan Kriterler Nelerdir? Peyzaj Mimarlığı 5. Kongresi, Adana, Adnan Menderes Üniversitesi Yayınları, 1290-1296.

Albayrak, S. (2000). Gülhane, Yıldız ve Emirgan Parklarının Kent Parkı İşlevi Açısından İrdelenmesi. Yüksek Lisans Tezi, İstanbul Teknik Üniversitesi Fen Bilimleri Enstitüsü, İstanbul.
Newbold, P. (1995). Statistics for Business and Economics, Prentice Hall Inc., 1016 pg, USA.

URL-1 (2019). Usküdar Doğal ve Kültürel Verileri, https://www.uskudar.bel.tr/userfiles/files/20152019\%20Stratejik\%20Plan.pdf, (Erişim Tarihi: 20.01.2019)

URL-2 (2019). TUIK Nüfus Verileri. http://tuik.gov.tr/HbGetirHTML.do?id=30709, (Erişim Tarihi: 15.04.2019)

URL-3 (2019). Örneklem Hesaplama. https://duranguler.com/ornek-hacmi-hesaplama, (Erişim Tarihi: 18.02.2019)

URL-4 (2019). Parklarımız. http://www.anadoluparkbahceler.com/, (Erişim Tarihi: 21.04.2019) 